\title{
The Mobilization of the Formal Normative Rules in an Educational Institution: A Sociological Study in Portugal
}

\author{
Sandro Serpa ${ }^{1,2}$ \\ ${ }^{1}$ Department of Educational Sciences (DCE), University of the Azores, Ponta Delgada, Azores, Portugal \\ ${ }^{2}$ University of the Azores, Interdisciplinary Centre of Social Sciences-CICS.UAc/CICS.NOVA.UAc, Portugal \\ Correspondence: Sandro Serpa, Department of Educational Sciences (DCE), University of the Azores, Campus \\ de Ponta Delgada, Apartado 1422, PT-9501-801 Ponta Delgada, Azores, Portugal. Tel: 351-29-665-0000. E-mail: \\ sandro.nf.serpa@uac.pt
}

Received: June 10, 2015 Accepted: July 30, 2015 Online Published: January 25, 2016

doi:10.5539/ies.v9n2p1 URL: http://dx.doi.org/10.5539/ies.v9n2p1

\begin{abstract}
The formal dimension can greatly condition the operation of an organization. The present article aims to study the mobilization of organizations' formal structures within educational institutions. To achieve this goal, I analyze the situations between 1858 and 1913 in which the bylaws and/or regulations of the Disadvantaged Children's Shelter of Horta (Asilo de Infância Desvalida da Horta-AIDH), the Azores, Portugal, are explicitly noted with different chairmen and administrations through documents found in the organization's archives. We find that these formal instruments are mobilized not only by the chairman and the administration but also by the governance, whether to justify the shelter's operation, legitimize decisions already made, or refer to the importance of these formal official normative guidelines. As a result, we find that this formal dimension is of the utmost importance, not only as a potential guiding framework but also for legitimizing action, even though it does not necessarily reflect the operations of an organization.
\end{abstract}

Keywords: institution, organization, formal normative rules, bylaws, regulations, education, management, Disadvantaged Children's Shelter of Horta (Asilo de Infância Desvalida da Horta), Portugal

\section{Introduction}

\subsection{The Relevance of Rules for Action in the Institution}

The scientific community knows that educational activities occur within "the high dynamics of external and internal environment" (Levina et al., 2015, p. 234). How reality is interpreted-representation-is important for delimitating reality in this environment and subsequent orientations for action.

According to Almeida (1990), representations

[...] are socially engendered and shared knowledge with several practical functionalities in the interpretation and control of reality. They constitute explanatory, communicative, and operative references. They name and classify, produce images that comprise meanings, assign sense, and assist in their structured diversities to reproduce social and cultural identities. Systematic preferences are encompassed in representations that are called values, which provide to those who adopt them [sic] guiding elements of behavior. (pp. 123-124)

Within the timeframe covered by this study, social representations of unprotected girls, as well as possible solutions, are materialized in children's and teenagers' foster homes in coordinated collective units (Serpa, 2015) _ organizations in which these girls share in communal living (Serpa, 2014a).

These organizations, in their specificities (Serpa, 2014a), have their action classified by "guidelines for action" (Lima, 1998; 2001, 2006, 2011a, 2011b), which establish formal standards and rules, such as bylaws and regulations that may work to legitimize their mission (Serpa, 2015).

This fact does not prevent a certain type of uncertainty, or even tension, from arising from the relative autonomy of the organization's operations in relation to this formal dimension. Actors have relative autonomy and may comply, either to a greater or lesser extent, with officially established requirements (Serpa, 2014a; Friedberg, 1993; Torres, 2004, 2006, 2011; Perrenoud, 1994; Silva, 2011; Lima, 2011b). Thus, "the long effect of a rule and 
its maintenance in the legal-formal plane cannot be therefore confused, the hierarchical and systematic appeals to its observance, nor the control provisions on their performance, with their effective update in the action plane" (Lima, 2011b, p. 174).

As elucidated by Alves da Silva (2011), an analysis solely focused on the formal dimension is inadequate for understanding how organizations operate because

[...] the vision of a visible facet of the organization based on formality, on the uniformity of behaviors, and on the predictability of results does not exclude - merely hides - the informal dimension underlying these processes, actions, and behaviors marked by uncertainty, ambiguity, infidelities, and conflicts (2011, p. 60).

The present study aims to contribute to the understanding of the importance of the formal structure, in the form of bylaws and regulations, by analyzing situations in which the formally instituted dimension is explicitly mobilized in the educational context of the Disadvantaged Children's Shelter of Horta (Asilo da Infância Desvalida da Horta - AIDH) in Portugal. It also contributes to overcoming "a certain hegemony [of the School] against the study of other non-school and non-formal educational phenomena" (Lima, 2011b, p. 148).

1.2 Guidelines for Action at the Disadvantaged Children's Shelter of Horta: Bylaws of 1860 and the Regulation of 1976

The AIDH, located in the city of Horta on Faial Island in the Azores in Portugal, was founded on December 28, 1858 - the feast day of the Innocent Saints in the Catholic Church—with the mission of helping "exposed" girls in situations of extreme poverty. This social unit of children and youths in a communal residence consisted of a collective shelter for unprotected children and youths (Lemos, 1958; Lobão, 1998; Fernandes, 2003, 2004; Serpa, 2014a, 2014b). The number of girls in the shelter reached a maximum of 28 girls between 1904 and 1906 and a minimum of six girls in 1858 (Lemos, 1958).

The shelter was established in a refurbished building that was originally the former Convent of Saint Anthony (Convento de Santo António), including its church and surrounding fence (Figure 1).

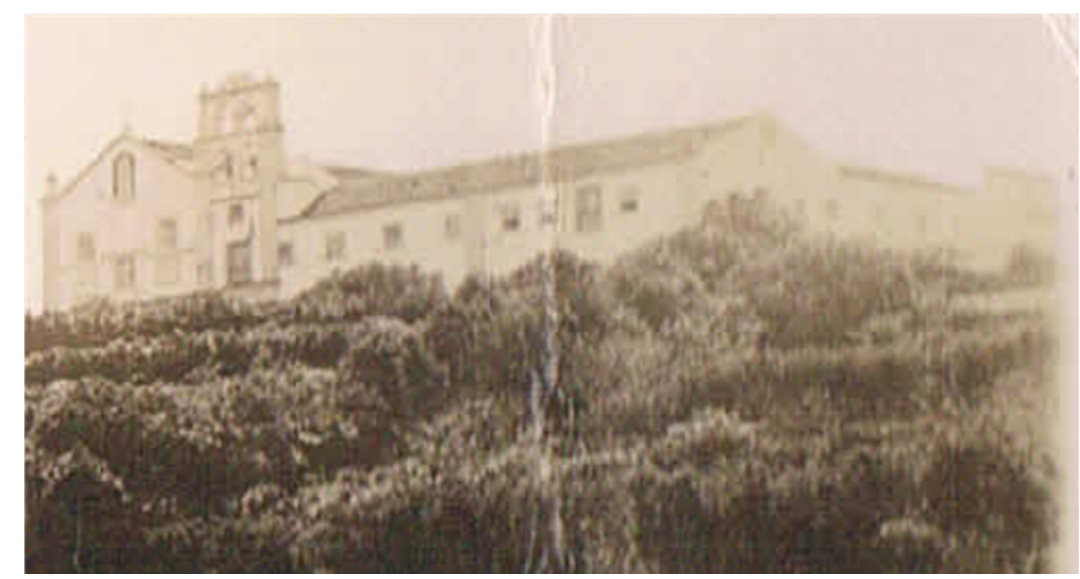

Figure 1. The former Convent and Church of Saint Anthony (Source: Lemos, 1958)

With regard to the formal structure of this shelter, the first bylaws were approved on May 9, 1860, approximately one and a half years after it started operations (Bylaws of the Brotherhood of St. Anthony and Disadvantaged Children's Shelter. January 10, 1876 [Estatutos da Confraria de Sto. António e Azylo de Infância Desvalida. 10 de Janeiro de 1876]).

The chairman of the shelter felt the need to refer to this institutional standardization as (Serpa, 2015) "established with all formalities of Law, and with the required safety, having its bylaws approved by Royal Charter of His Majesty of May 7, 1860, and the Decree of April 15, of the same year, as well as bylaws by this Civil Government" (Information on the shelter's status from the acknowledgement of a donation, January 7, 1861, in the Records of Official Letters received by the Disadvantaged Children's Shelter from 1858 to 1862 [Registro de Officios recebidos no Asylo de Infância Desvalida. Desde 1858 a 1862]).

With regard to regulations, the importance of the written rules, which established the operation of the 
organization, is highlighted in these Bylaws of 1860: "the administration, regime, and policy of the Disadvantaged Children's Shelter will be carried out in compliance with the regulation" (Chapter 9, Article 58). This normative document also states that "a regulation, prepared by the administration, shall set forth the roles that the chairman and the administration will perform in their different functions" (Bylaws of 1860, Chapter 7, Article 55, §1, §2). In addition to being very thorough in explaining the structure and mode of operations of the Shelter (even with regard to everyday life), it is worth noting the centrality that the Regulation of 1876 assigned to the chairman regarding the control of the institution's operations. The shelter was managed by a chairman who was appointed by the civil governor and a board of directors who were elected from among the Brotherhood of Saint Anthony of Padua (Confraria de Santo António de Pádua), whose mission was the supervision of the Church, the former Convent of Saint Anthony, and the AIDH (Bylaws of the Brotherhood of St. Anthony and Disadvantaged Children's Shelter. January 10, 1876).

This normative framework (bylaws and regulations) was in effect until 1913: "the shelter's bylaws were approved by the decree of April 25, 1861, and they are still in force without any amendments" (Information on the Shelter, September 9, 1908, in a correspondence issued by the Brotherhood of St. Anthony of Padua and Disadvantaged Children's Shelter. From Jan 2, 1905 to Dec 31, 1913 [Correspondência expedida da Confraria de S. António de Pádua e Asylo de Infância Desvalida. Desde 2-1-1905 a 31/12/1913]).

\section{Method}

\subsection{Study Objective}

The present study aimed to analyze the mobilization of the AIDH's formal rules from 1860 (when the bylaws were approved) to 1913 (when they were revoked in favor of a new statutory system) through situations that explicitly referenced the bylaws and/or regulations by which the AIDH was governed.

\subsection{Research Operation}

This research was supported by a documentary study (Bardin, 1995) that focused on references to the archives of the Children's Home of Saint Anthony [Casa de Infância de Santo António] (the current name of the AIDH). The documentary's data collection took place over the long term and produced a large volume of documentation that became essential and central to the present diachronic study. Our attention was primarily focused on internal institutional documentation that referenced the organization or that formally described or implied compliance with the organization (bylaws and regulations), as well as minutes, books, and overseas correspondence. Because the documentation is over 100 years old, we opted to bring spelling in line with today's standards for our in-text citations.

We used this documentation to create the following dimensions, which served as guidelines for our presentation of results: the curriculum of the shelter's girls, the staff changes, the criticisms of the shelter's operations, and finally, the relevance assigned to bylaws and regulations.

\section{Results}

\subsection{The Curriculum of the Shelter's Girls}

The following institutional order was highlighted by the AIDH administration in order to justify procedures related to the education provided to the shelter's girls: "learning the subjects in compliance with the law" (Session of April 4, 1892, in the minutes of the Disadvantaged Children's Shelter of Horta. From Oct 1, 1883, to Apr 7, 1897 [Actas do Asylo de Infância Desvalida da Horta. Desde 1-10-1883 a 7-4-1897]).

The bylaws, and especially the Regulations, were very thorough with respect to the lives of the students in the shelter. For example, with regard to the syllabus and study, education, and learning plans of the shelter's girls, the Regulation of 1876 established three educational dimensions: physical education (which referred to the domestic service at the shelter), moral and religious education, and literary education:

[...] the shelter's girls will be equally trained in the domestic jobs and services appropriate to their gender, such as cleaning and making the bed and kitchen and table service, and, in addition, they will learn to wash, repair, cut, and iron clothes (Regulation of 1876, Article 119).

Reading, writing, the four operations of whole and decimal numbers, the metric system, grammatical exercises, the general principles of morality, civility, Christian doctrine, sacred story elements of the Old and New Testament, sewing, knitting socks, embroidery, spinning, and other works appropriate to their gender (Regulation of 1976, Article 118). 
Table 1. Distribution of time for exercises and application of the shelter's girls

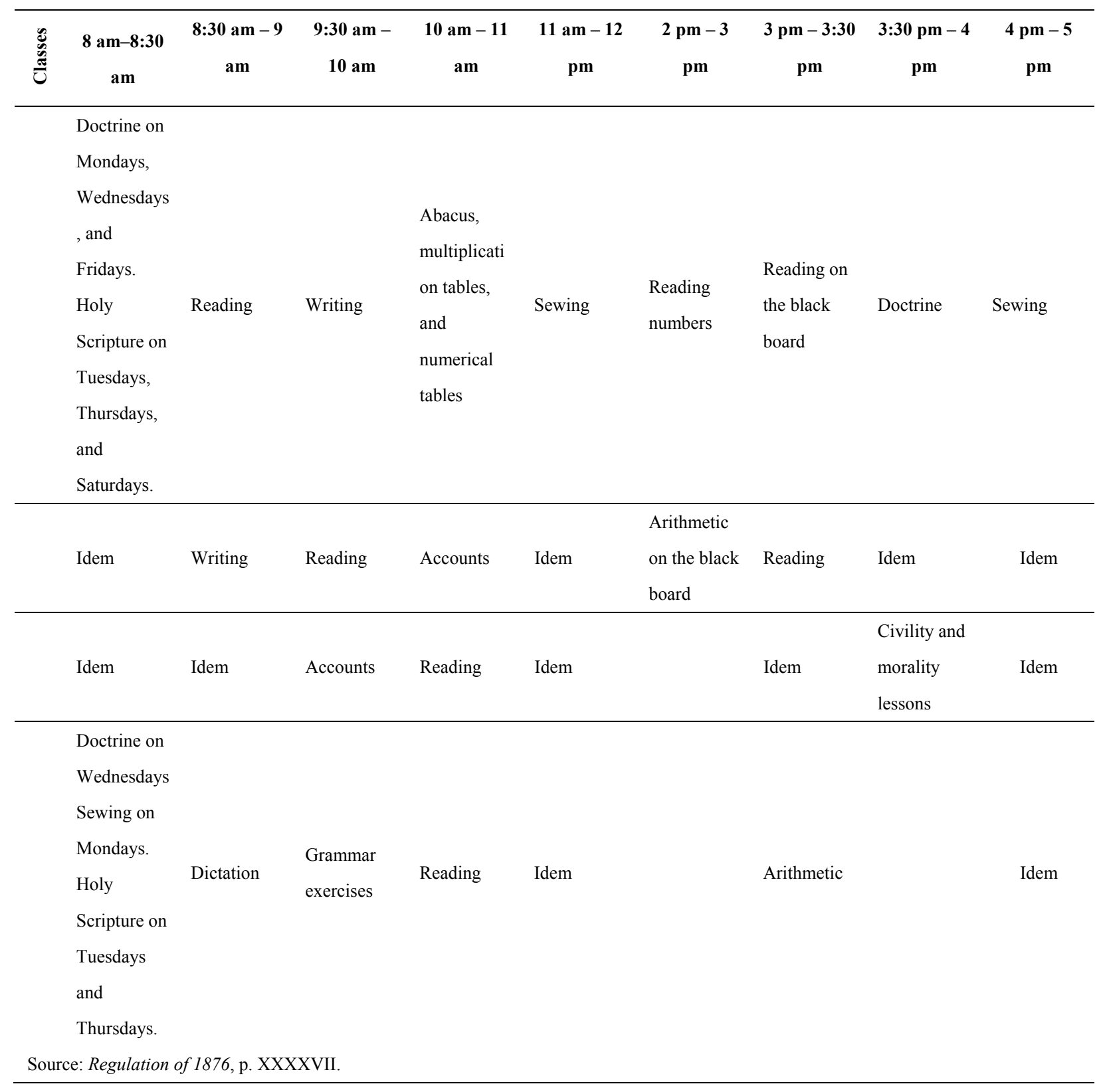

All of these procedures comply with the shelter's function of "inspiring a religious feeling in them, and the perfection of moral and social virtues and therefore quenching their curiosity about the objects presented for their contemplation and assigning them to applicable jobs" (Regulation of 1876, Article 130).

In this same regulation, an exception was made for the preparations of certain girls if they showed a "certain vocation for the teaching profession" (Article 120): "they will also be trained in the practice of primary education since the early childhood classes" Article 121 also had the following addendum: "only the shelter's girls who exhibit a certain vocation for the teaching profession will be trained in the exercises addressed in Article 127 of this regulation, upon deliberation by the chairman" (Article 136).

\subsection{Staff Changes}

At the staff level, the autonomy given to the principal (the in-house teacher directly responsible for the shelter's operations) triggered several instances of tension regarding her actions in relation to the administration, which was made up of only males. 
Some examples of bylaws' mobilization and/or regulation by the shelter's chairman justified and legitimized decisions regarding changes in staff, specifically dismissals of the shelter's principal and teacher: "3-The appointment, suspension, and dismissal of all employees of the Brotherhood who do not depend on election" (Bylaws of 1860, Chapter 6, Article 46):

Authorized by no. 3 of Article 46 of the respective Bylaws: it is set forth that, after providing inventory and delivering all that is under your responsibility, you are dismissed from your functions as teacher and principal, which you perform in this establishment, and you shall leave by the $30^{\text {th }}$ day of the current month (Official Letter of November 13, 1871, in correspondence found from 1871 on the dismissal of the shelter's principal [Correspondência encontrada de 1871 sobre a demissão da Diretora do Asilo]),

Another situation occurred on July 13, 1873 with the dismissal of the shelter's principal: "considering that you do not perform your functions according to the bylaws of this shelter and my orders" (official letter sent to the shelter's principal, in the Copy of Official Letters of the Brotherhood of Saint Anthony and Disadvantaged Children's Shelter. From April 1872 to June 14, 1878 [Cópia de Oficios da Confraria de Santo António e Asylo de Infância Desvalida. Desde Abril de 1872 a 14/6/1878]).

The chairman also claimed that the principal, among other things, had a lack of knowledge about the Bylaws of 1860 and the Regulation of 1876 (Instrument of investiture, July 1, 1895, in the minutes of the Disadvantaged Children's Shelter of Horta. From Oct $1^{\text {st }}, 1883$ to Apr $7^{\text {th }}, 1897$ [Actas do Asylo de Infância Desvalida da Horta. Desde 1-10-1883 a 7-4-1897]). This situation led to the principal's dismissal by the chairman, "who forced him to make use of the option granted in $\S 3$ of Article 4 of the Bylaws, dismissing her yesterday with a letter in which he ordered her to turn in her keys to the students' representative" (Session of October 16, 1895 in the minutes of the Disadvantaged Children's Shelter of Horta. From Oct 1, 1883 to Apr 7, 1897).

For this dismissal, the following reasons were presented by the chairman to the Board of Directors, among others:

- Physical aggression against the students when the regulation in Article 144 forbids the use of corporal punishment ("Physical punishment is expressly forbidden. The principal is responsible for any breach of this precept") (Regulation of 1876, Article 144);

- Noncompliance with the schedules of the regulation and her duties as principal, never waking up at the established time.

In another situation about dividing tasks among the staff, it was decided, "in compliance with the bylaws and regulations of the shelter", that two students would share the place of "principal's assistant" (one designated for school work and the other appointed for internal work in the shelter) (Session of November 30, 1884 in the minutes of the Disadvantaged Children's Shelter of Horta. From Oct 1, 1883, to Apr 7, 1897).

\subsection{Criticisms of the Shelter's Operations}

Although rare, there are examples of explicit criticisms of the shelter's operations. In one situation, which occurred on January 29, 1878, Civil Governor Visconde de Castilho questions the administration's actions in the following terms:

[...] according to Article 8, of the regulation of this shelter, the Board of Directors shall gather once a month, and extraordinarily whenever deemed necessaryconvenient, and because (for reasons unfamiliar to your good will) this useful regulatory provision has not been followed, I hereby request that you provide the reasons that have given rise to this omission. Therefore, I wish that you provide me the names of the current inspectors that the board appoints, according to no. 3 of Article 7. (Official letter of the Civil Governor requesting information, in The Copy of Official Letters of the Brotherhood of Saint Anthony and Disadvantaged Children's Shelter. From April 1872 to June 14, 1878)

This letter names the following regulatory provision, which, as one of the competences of the shelter's administration and one of the forms of surveillance of its operation, addresses " 3 -The appointment of three teachers" (Regulation, Article 7).

The shelter's administration promptly appointed a teacher for a vacant position and replaced a deceased administration member. As a result, it openly sought to comply with the superior recommendations justified by the regulation "in compliance with the recommendations of this board" and the civil governor regarding the teachers and "[that] was now made, by superior determination" (Substitution of a member of the Board of Directors, February 14, 1878, in the Copy of Official Letters of the Brotherhood of Saint Anthony and Disadvantaged Children's Shelter. From April 1872 to June 14, 1878). 


\subsection{Importance Assigned to Bylaws and Regulations}

The relevance of this formal normative dimension is visible in the mobilization of the regulations at the request by the president of the Municipal Chamber of Horta on May 16, 1877. This mobilization was made to justify the admission of a particular girl: "according to the regulation of the shelter, girls exposed or abandoned by their parents have preference in the admission; I hereby request compliance" (Request of the president of the Municipal Chamber of Horta, in the Copy of Official Letters of the Brotherhood of Saint Anthony and Disadvantaged Children's Shelter. From April 1872 to June 14, 1878).

Another situation that demonstrates the relevance assigned to the bylaws and regulations is the Sociedade Amor da Patria's response to the possibility raised by the civil governor of assuming management of the shelter. The response listed the following conditions, which were recorded in the minutes of the meetings of the associates of the Sociedade Amor da Pátria, of March 14, 1872):

$[\ldots]$ the entire administration belongs to him, which will be regulated in bylaws developed by the general meeting that clearly define the composition, appointment and duties of the shelter's administration, of the respective employees, the applicable bookkeeping, ways of receiving and managing, obligations inherent to the Divine cult, and in general, whatever may contribute to the best physical, moral, and religious education of the shelter's girls. That in such regard, the bylaws will designate a committee of three respectable ladies, annually invited by the administration to internally manage the same shelter. The bylaws will be formulated according to the general precept that the institute's administration is a delegation of the "Amor da Pátria" Association. (Official Letter of the Civil Governor on the delivery of the shelter's administration to the Amor da Pátria Association, March 19, in correspondence found from 1872 on Amor da Pátria Association [Correspondência encontrada de 1872 sobre a Sociedade Amor da Pátria]).

Furthermore, the reference to a situation in which the chairman found that "[the principal] is trying to promote a reform in the Bylaws to enhance her role" is enlightening (Session of October 16, 1895, in the minutes of the Disadvantaged Children's Shelter of Horta. From Oct 1, 1883, to Apr 7, 1897. [Actas do Asylo de Infância Desvalida da Horta. Desde 1-10-1883 a 7-4-1897]).

Another situation showing the relevance of this dimension of formal structures was a series of changes to external context and subsequent statutory reform, as I discuss below. Upon the establishment of the Republic of Portugal on October 5, 1910, a new chairman of the shelter was to be appointed by the civil governor, according to the Permit of December 3, 1910 (Session of December 3, 1910, in the minutes of the Brotherhood of Saint Anthony of Padua and Infant Dom Luis Shelter. From July 1, 1903 to Sep 4, 1912. [Actas da Confraria de Santo António de Pádua e Asylo do Infante Dom Luis. Desde 1-7-1903 a 4-9-1912]). The investiture of a new administration was also to take place in the session on July 1, 1911 (Investiture) (Minutes of the Brotherhood of Saint Anthony of Padua and Infante Dom Luis Shelter. From July 1, 1903, to Sep 4, 1912).

Currently, the Regulation of 1876 and Bylaws of 1860 remain in effect, as is evident from the following examples regarding the "visitor", the staff, the celebration of mass due to the death of brothers from the Brotherhood, the departure of the shelter's girls, and the festivities:

- As a surveillance norm, which is a reference to the concern for compliance with the regulatory standards which notes that "a member of the Board of Directors will be designated every month to visit the shelter; and in the capacity of visitor, he shall 1-Visit the shelter daily if he can, at different times of the day" (Article 83, Regulation of 1876). A monthly "visitor" of the shelter was appointed among the members of the board at the first session of the administrative committee. Mention of this visitor is also repeated in several minutes of following sessions of the administration (Until the session of September 4, 1912, in the minutes of the Brotherhood of Saint Anthony of Padua and Infante Dom Luis Shelter. From July 1, 1903 to Sep 4, 1912).

- At the investiture session, the appointment of a bookkeeper is found, mobilizing the Regulation of 1876, which is then in force and is acknowledged by this administration: "due to the considerable amount of bookkeeping service and in conformity with Article 22 of the bylaws of this shelter, approved by permit of the Civil Governor of Horta, on January 8, 1876" (Session of July 1, 1911 (Investiture), in the minutes of the Brotherhood of Saint Anthony of Padua and Infante Dom Luis Shelter. From July 1, 1903 to Sep 4, 1912).

- For the death of brothers, the board decided "that, in conformity with number three of Article six of the bylaws, two masses were celebrated at the Church of Saint Anthony, upon vote, for the deceased brothers" (Session of June 6, 1912, in the minutes of the Brotherhood of Saint Anthony of Padua and Infante Dom Luis Shelter. From July 1, 1903 to Sep 4, 1912). 
- On the departure of students, compliance with the Regulation of 1876 also seems to be followed, with such departure needing approval and a certificate from the parish or administrator with regard to how it can support the departure and both the approval and the certificate and the decision of the administration being filed with the secretary of "this Brotherhood" (Session of February 6, 1913; Session of March 9, 1913, in the minutes of the Brotherhood of Saint Anthony of Padua and Infante Dom Luis Shelter. From July 1, 1903, to Sep 4, 1912); "drafting an instrument of delivery in compliance with the bylaws of the shelter" (Session of December 3, 1910, in the minutes of the Brotherhood of Saint Anthony of Padua and Infante Dom Luis Shelter. From July 1, 1903 to Sep 4, 1912).

- In another explicit reference to the concern for compliance with statutory rules, "festivities that this brotherhood has to celebrate [must occur] in conformity with its bylaws" (Session of January 7, 1911, in the minutes of the Brotherhood of Saint Anthony of Padua and Infante Dom Luis Shelter. From July 1, 1903 to Sep 4, 1912).

At the festival of Saint Anthony, the patron of the brotherhood that manages the Shelter and the name of the former church and convent in which it was installed, it is noted that the new external precepts of secularization caused by the establishment of the republic, are a great novelty: "[Thank you for the invitation to attend the festival of Saint Anthony;] however, I cannot accept it because the current legal precepts do not allow me to officially attend any religious acts" (From the Civil Governor of the District of Horta, June 15, 1911, in correspondence received by the Brotherhood of Saint Anthony of Padua and the Disadvantaged Children's Shelter. From Dec 15, 1910 to Dec 10, 1917).

In an extraordinary session of the general meeting of the "Brotherhood of Saint Anthony of Padua and Disadvantaged Children's Shelter" on October 27, 1912 (Minutes of the Brotherhood of Saint Anthony of Padua and the Disadvantaged Children's Shelter. From Oct 27, 1912 to Mar 4, 1921), the project of the new Bylaws was approved "in conformity with the law of separation of religion from the state [...], thus, the bylaws of this Brotherhood are amended in accordance with the law". The approval is sent "enclosed with a copy of the minutes of the session of the $27^{\text {th }}$ of the current month of the general meeting of this Brotherhood of Saint Anthony of Padua and Disadvantaged Children's Shelter, as well as its bylaws, duly reformed in compliance with the law" (To the Administrator of the Council of Horta, October 30, 1912, in correspondence issued by the Brotherhood of Saint Anthony of Padua and the Disadvantaged Children's Shelter. From Jan 2, 1905, to Dec 31, 1913).

On May 8, 1913, the Civil Governor of the District of Horta approved (Document of approval of the Bylaws of 1912 by the Civil Governor of Horta, 1913) the new bylaws that governed the institution.

In the approval document for these bylaws, (hereafter referred to as Bylaws of 1913), the following is stated:

[...] in compliance with the representations made by the Brotherhood of Saint Anthony of Padua, from the city of Horta, Faial island, and according to the applicable provisions of the administrative code and of the laws of April 20, 1911, and July 10, 1912: and whereas said Brotherhood was, prior to the law of April 20, 1911, a charity association with the purpose of maintaining the disadvantaged children's shelter as per its bylaws approved by charter of May 9,1860, in which there was nothing that would contradict the provisions of said law, for which Article 39 of the same law was not applicable, and thus, said brotherhood was not in accordance with the ordinance of November 18, 1911;

Whereas the new bylaws that the Brotherhood voted on at the general meeting of October 27, 1912 and were entered in this Civil Government on the $31^{\text {st }}$ of the same month, and whereby they shall substitute the aforementioned bylaws, are in perfect agreement with the aforementioned law of April 20, 1911, as well as additional legislation on the matter (Document of Approval of the Bylaws of 1912 by the Civil Governor of Horta).

In the same Bylaws of 1913, the following is highlighted:

[...] in cases not mentioned in these bylaws, the brotherhood will be governed by the laws and general regulations that are in force, and especially by the law of April 20,1911, which the brotherhood declares it will adopt as its main statutory law in all its provisions, whether related to precepts or prohibitions (Bylaws of 1913, Chapter 9, General provisions, Article 52).

Once again, we see the importance and centrality, at that time, of the Law of April 20, 1911 - the law about the separation of church and state - and, in the case of the AIDH, a need to explain its statutory adherence to the new regime in compliance with few, but very significant, differences between those Bylaws of 1913 and the Bylaws of 1860. On this matter, we highlight the very significant exception that arises in these Bylaws of 1913: the 
prohibition against electing ministers of any religion or church as members of the administration (Chapter 3, Article 12,4) as more than one example, at the least, of the state-religion separation in this normative dimension.

\section{Discussion}

This article seeks to study the mobilization of the formal structure within an educational organization by analyzing situations between 1858 and 1913 in which the bylaws and/or regulation of the Disadvantaged Children's Shelter of Horta in the Azores, Portugal, with different chairmen and administrations, were explicitly noted. We did this by using documentation contained in the organization's archives. To summarize our findings, we found that not only the chairman and administration mobilized these instruments, but that the governance also did, whether to justify the operation of the shelter, legitimize decisions made, or even to refer to the importance of the official formal normative guidelines.

These instances occur in a context of an educational institution with normative guidelines based on an education focusing on Catholic morality. This context aspired to educate students to become honest, married women, mothers, believers, and domestic workers, and thereby maintained the social condition of the girls in these shelters. These girls would leave to serve in a family's home or get married and live a morally honest life, all of which were considered good possibilities for their future (Serpa, 2014b).

My empirical findings, then, show that the formal dimension can greatly condition the operation of an organization. This implies that this dimension of the institution is noteworthy, despite not necessarily reflecting the operation of an organization. In fact, it is of utmost importance, not only as a guiding framework but also for legitimizing its actions. As a result, I empirically find that "an organization is a group called by a very strong and legitimate organizing power, both in the interior and exterior" (Perrenoud, 1994, p. 134).

This analysis of one of the bureaucratic dimensions - compulsory legal formal standards (bylaws and regulations) - allows the verification that mobilizing these legal rules allows for the "control" and "coercion" of the regulation of the established order, as well as the "legitimacy" of those who exercised this regulation and its decisions (Silva, 2011):

Bureaucracy plays a unifying and integrating role in organizational action in a context of conflictual dispute and wide ambiguities because it represents the "calculated space for maneuvering" within which organizational actors interact and where organizational dynamics proceed by guaranteeing excessive deviations that can endanger the minimum organizational unity and cohesion that ensure the maintenance and continuity of the organization. (p. 95)

One should take into account the formal dimension of bylaws and regulations, the central elements in the legitimacy of decision-making, and the critical evaluation of the various actors involved in operating the organization, as elements that may be central to justifying that organization's operations and its administration's decision-making.

\section{References}

Almeida, J. F. de (1990). Portugal - Os próximos 20 anos [Portugal-The next 20 years]. VIII vol. Valores e representações sociais. Lisboa: Fundação Calouste Gulbenkian.

Bardin, L. (1995). Análise de Conteúdo [Content Analysis]. Lisboa: Edições 70.

Fernandes, A. A. S. (2003). Uma Obra Ímpar Abençoada por Santo António [A Unique Work Blessed by St. Anthony]. Lisboa: Editorial Minerva.

Fernandes, A. A. S. (2004). Uma Obra Ímpar Abençoada por Santo António [A Unique Work Blessed by St. Anthony]. Casa de Infância de Santo António-Horta. Lisboa: Edição de autor.

Friedberg, E. (1993). Le pouvoir et la règle. Dynamiques de l'action organisée. Paris: Éditions du Seuil.

Lemos, R. R. G. de (1958). Asilo de Infância Desvalida da Horta [Disadvantaged Children's Shelter of Horta]. 1858-1958. Trabalho manuscrito de comemoração de um século de existência.

Levina, E. Y., Kamasheva, Y. L., Gazizova, F. S., Garayeva, A. K., Salpykova, I. M., Yusupova, G. F., \& Kuzmin, N. V. (2015). A process approach to management of an educational organization. Review of European Studies, 7(4), 234. http://dx.doi.org/10.5539/res.v7n4p234.

Lima, L. C. (1998). A Escola como organização e a participação na organização escolar. Um estudo da Escola Secundária em Portugal (1974-1988) [The school as an organization and participation in school organization. A study of Secondary Education in Portugal (1974-1988)]. Braga: Centro de Estudos em Educação e Psicologia, Instituto de Educação e Psicologia, Universidade do Minho. 
Lima, L. C. (2001). A escola como organização educativa: uma abordagem sociológica [The school as an educational organization: a sociological approach]. São Paulo: Cortez Editora.

Lima, L. C. (2006). 1. Concepções de escola: para uma hermenêutica organizacional [School conceptions: for an organizational hermeneutics]. In L. C. Lima (Ed.), Compreender a escola. Perspectivas de análise organizacional (pp. 15-69). Porto: Edições ASA.

Lima, L. C. (2011a). Concepções de escola: para uma hermenêutica organizacional [School conceptions: for an organizational hermeneutics]. In L. C. Lima (Ed.), Perspectivas de análise organizacional das escolas (pp. 15-57). Vila Nova de Gaia, Portugal: Fundação Manuel Leão.

Lima, L. C. (2011b). Administração escolar: Estudos [School Administration: Studies]. Porto: Porto editora.

Lobão, C. M. G. (1998). Casa de Infância de Santo António - Subsídios para a sua História [Children’s Home of St. Anthony - Subsidies for its History]. Horta: Casa de Infância de Santo António.

Perrenoud, P. (1994). A organização, a eficácia e a mudança, realidades construídas pelos atores [The organization, effectiveness and change, realities constructed by the actors]. In M. G. Thurler, \& P. Perrenoud (Eds.), A Escola e a Mudança. Contributos sociológicos (pp. 133-159). Lisboa: Escolar Editora.

Serpa. (2014a). O contributo do conceito de instituição total para uma leitura empírica de um contexto educativo [The contribution of the concept of total institution for an empirical reading of an educational context]. ISBN: 978-989-97981-2-0. 40 anos de democracia(s): progressos, contradições e prospetivas. Atas do VIII Congresso Português de Sociologia. Lisboa: Associação Portuguesa de Sociologia. Retrieved from http://www.aps.pt/viii_congresso/VIII_ACTAS/VIII_COM0101.pdf.

Serpa. (2014b). A utilização de tipo ideal como estratégia metodológica na apreensão da cultura organizacional [The use of the ideal type as a methodological strategy in the seizure of organizational culture]. Associação Portuguesa de Sociologia (org.). 40 anos de democracia(s): progressos, contradições e prospetivas. Atas do VIII Congresso Português de Sociologia. Lisboa: Associação Portuguesa de Sociologia. Retrieved from http://www.aps.pt/viii_congresso/VIII_ACTAS/VIII_COM0143.pdf.

Serpa. (2015). Regulação e autonomia na procura de legitimidade na fundação do Asilo de Infância Desvalida da Horta [Regulation and autonomy on the legitimacy of demand in the foundation of the Disadvantage Children's Shelter of Horta]. In A. P. Almeida, L. L. Dinis, \& G. R. da Silva (Eds.), Políticas e Práticas de Administração e Avaliação na Educação Ibero-Americana-Actas do IV Congresso Ibero-Americano de Políticas e Administração da Educação-2014. Lisboa: Fórum Português de Administração Educacional.

Silva, E. A. da (2011). Um olhar organizacional à luz das perspectivas de análise burocrática e política [An organizational look in light of the prospects for bureaucratic and political analysis]. In L. C. Lima (Ed.), Perspectivas de análise organizacional das escolas (pp. 59-108). Vila Nova de Gaia, Portugal: Fundação Manuel Leão.

Torres, L. L. (2006). Cultura organizacional em contexto escolar [Organizational culture in schools]. In L. C. Lima (Ed.), Compreender a Escola. Perspectivas de análise organizacional (pp. 133-195). Porto: Edições ASA.

Torres, L. M. de L. (2004). Cultura organizacional em contexto educativo. Sedimentos culturais e processos de construção do simbólico numa escola secundária [Organizational culture in educational context. Cultural sediments and symbolic construction processes in a secondary school]. Braga: Centro de Investigação em Educação do Instituto de Educação e Psicologia da Universidade do Minho

Torres. L. L. (2011). Cultura organizacional em contexto escolar [Organizational culture in schools]. In L. C. Lima (Ed.), Perspectivas de análise organizacional das escolas (pp. 109-152). Vila Nova de Gaia, Portugal: Fundação Manuel Leão.

\section{Archives of the Disadvantaged Children's Shelter of Horta}

Bylaws of the Brotherhood of St. Anthony and Disadvantaged Children's Shelter. January 10, 1876. (Estatutos da Confraria de Sto. António e Azylo de Infância Desvalida. 10 de Janeiro de 1876.) (contains Bylaws of 1860 and Regulation of 1876).

Copy of Official Letters of the Brotherhood of Saint Anthony and Disadvantaged Children's Shelter. From April 1872 to June 14, 1878 (Cópia de Ofícios da Confraria de Santo António e Asylo de Infância Desvalida. Desde Abril de 1872 a 14/6/1878.) 
Correspondence found from 1871 on the dismissal of the shelter's principal (Correspondencia encontrada de 1871 sobre a demissão da Diretora do Asilo.)

Correspondence found from 1872 on the Amor da Pátria Association (Correspondência encontrada de 1872 sobre a Sociedade Amor da Pátria.)

Correspondence issued by the Brotherhood of St. Anthony of Padua and Disadvantaged Children's Shelter. From Jan 2, 1905, to Dec 31, 1913 (Correspondência expedida da Confraria de S. António de Pádua e Asylo de Infância Desvalida. Desde 2-1-1905 a 31-12-1913.)

Correspondence received by the Brotherhood of St. Anthony of Padua and Disadvantaged Children's Shelter. From Dec 15, 1910, to Dec 10, 1917 (Correspondência recebida pela Confraria de S. António de Pádua e Asilo de Infância Desvalida. Desde 15-12-1910 a 10-12-1917.)

Document of approval of the Bylaws of 1912 by the Civil Governor of Horta, 1913.

Minutes of the Brotherhood of Saint Anthony of Padua and Infante Dom Luis Shelter. From July 1, 1903, to Sep 4, 1912 (Actas da Confraria de Santo António de Pádua e Asylo do Infante Dom Luís. Desde 1-7-1903 a 4-9-1912.)

Minutes of the Disadvantaged Children's Shelter of Horta. From Oct 1, 1883, to Apr 7, 1897 (Actas do Asylo de Infância Desvalida da Horta. Desde 1-10-1883 a 7-4-1897.)

Record of Official Letters received at the Disadvantaged Children's Shelter. From 1858 to 1862 (Registo de Officios recebidos no Asylo de Infância Desvalida. Desde 1858 a 1862.)

\section{Copyrights}

Copyright for this article is retained by the author(s), with first publication rights granted to the journal.

This is an open-access article distributed under the terms and conditions of the Creative Commons Attribution license (http://creativecommons.org/licenses/by/3.0/). 